\title{
С.Ф. Татауров
}

\section{ПРОЦЕССЫ КОНСОЛИДАЦИИ СИБИРСКИХ ТАТАР ДО И ПОСЛЕ ПРИСОЕДИНЕНИЯ СИБИРИ К РОССИИ}

\author{
Статья подготовлена при поддержке Российского научного фонда. Проект № 14-50-00036 \\ «Мультидисииплинарные исследования в археологии и этнографии Северной и Центральной Азии».
}

\begin{abstract}
Показана значимость археологических материалов для анализа процесса консолидации сибирских татар в XVI-XVII вв. Рассматривается проблема оседания и формирования тюркоязычного населения Западной Сибири во II тыс., которая выражалась в складывании единого культурного, языкового и религиозного пространства. Приводятся причины длительности этого процесса, анализируются факторы, препятствующие или способствующие сближению отдельных групп населения. Показана роль российской администрации, ее действий по созданию новой для Сибири территориально-административной системы, распространению православия и т.д. Особое внимание уделено ходу исламизации населения уже в рамках российского государства после прихода русских, роли в этом процессе родовой татарской знати.

Ключевые слова: Сибирь; население; экономика; религия; консолидация.
\end{abstract}

Процесс консолидации тюркоязычного населения Западной Сибири занял значительный период времени, фактически все II тыс. н.э. Территория лесостепной зоны Западной Сибири с проживавшим на ней населением к середине XVI в. представляла собой, выражаясь археологической терминологией, историко-культурную общность. В целом для всего региона это проявлялось в определенной близости материальной и духовной культуры с локальными вариантами, тяготеющими к долинам крупных рек - Тоболу, Ишиму, Иртышу и Оби. Во второй половине XVI в. вся эта территория с проживающим на ней населением оказалась объединенной в границах одного государства - Сибирского ханства. К этому моменту сформировались большие региональные этнические группы сибирских татар [1]. После присоединения Западной Сибири к Российскому государству эти группы оказались в составе нового государства и продолжилось их социальноэкономическое сближение, что привело к сложению этноса - сибирских татар.

Продолжительность процесса сближения тюркоязычного населения была обусловлена несколькими факторами. Прежде всего, значительную роль в этом сыграло то, что их переселение в Западную Сибирь растянулось на более чем тысячу лет. Немалое значение имели и места выхода групп тюркоязычного населения, которые варьировались от предгорий Алтая до Средней Азии и Поволжья. На длительность процесса влияли природно-географические условия территорий, где селились мигранты, это в первую очередь долины крупных рек - Оби, Иртыша, Ишима, которые отделены друг от друга огромными труднопроходимыми болотными массивами. Это серьезно ограничивало развитие социально-экономических отношений между отдельными группами.

Собственно процесс формирования единого этноса сибирских татар начался с включением лесостепной полосы Западной Сибири в Монгольскую империю. Местная родовая элита оказалась поднятой сразу на несколько ступенек вверх согласно принятой в этом государственном образовании иерархии. «Создание в Улусе Джучи иерархии кланов во главе с джучидами трактовалось не просто как учреждение государства, а как акт социального творения, упорядочения микрокосма» [2. С. 193]. Как бы ни была номинальной центральная власть в сибирских тюрко-татарских государственных образованиях - осознание населением того, что они являются частью большого государства, у них есть верховный правитель и глава рода теперь руководит родом от его имени, - сыграло определяющую роль в его консолидации. Сбор налогов, выполнение общественных и государственных повинностей и работ, распространение ислама, строительство новых путей сообщения и развитие торговых отношений - все это сближало население лесостепи.

На момент присоединения Западной Сибири к Московскому царству происходит определенная унификация хозяйства, которое по своей структуре становится комплексным - состоящим из присваивающих отраслей - охоты, рыболовства и собирательства и производящих - скотоводства и земледелия. В зависимости от природных условий у отдельных групп приоритетными были те или иные отрасли хозяйства. Но у всех групп населения наблюдались общие традиции - в скотоводческой отрасли сохранялись коневодство и овцеводство, в земледелии преобладала мотыжная обработка почв и т.д.

Археологические материалы первой половины II тыс. н.э. при всем многообразии населения лесостепной полосы Западной Сибири дают нам довольно устойчивый тюркизированный фон по всем ключевым элементам материальной и духовной культуры.

Практически все группы переселились в каркасностолбовые слабо углубленные в почву жилища с чува- 
лами для обогрева и приготовления пищи. Наиболее наглядно в этом плане выступают материалы городища «Кучум-гора», раскопанного Р.Д. Голдиной [3. С. 138159], и городища Екатерининское V, исследованного В.Н. Чернецовым, В.А. Могильниковым и А.В. Матвеевым [4. С. 65-66]. Помимо конструкций жилищных комплексов наблюдается определенная схожесть и в общей планиграфии поселенческого комплекса, линейном расположении построек при их тяготении к 23 центрам.

В погребальном обряде наблюдаются постепенное уменьшение использования огня, углубление могильных ям, распространение деревянных перекрытий и превалирование северо-западной ориентации. При всем многообразии ориентации погребений и устройстве надмогильных сооружений можно выделить некоторые моменты, которые, по мере распространения и укрепления ислама, в конечном итоге привели к значительной идентичности погребального обряда для всех групп сибирских татар. В первую очередь это касается расположения погребальных комплексов относительно поселений, устройства подъезда к ним, ограждения от остальной территории, строительства общественных строений и определенной планиграфии захоронений.

В посуде мы фиксируем переход от неорнаментированной или слабо орнаментированной грубой по технологии керамики к более высокому уровню техники изготовления сосудов и покрытие их орнаментами местного, преимущественно угорского населения. Далее, в XVI в. на памятниках сибирских татар выделяется комплекс круглодонной керамики, украшенной по всей поверхности рядами подтреугольных или семечковидных штампов. Эта керамика фиксируется практически на всех крупных поселенческих комплексах Сибирского ханства. О том, что этот орнамент постепенно становится наиболее значимым для татар, свидетельствует тот факт, что после присоединения Сибири к Московскому царству он сохраняется на посуде, сделанной по русскому образцу до начала XVIII в.

В одежде и украшениях все большее место занимают южные по изготовлению вещи - кожаные пояса с сердечковидными пряжками, ожерелья из пастовых разноцветных бус, кольца и перстни со вставками из полудрагоценных камней. Развитие торговых отношений принесло распространение в одежде мануфактурных тканей, в том числе среднеазиатского и китайского шелка. Следует отметить, что костюм тюркоязычного населения Западной Сибири оказался достаточно устойчивым для каждой локальной группы и сохранил свои основные черты до середины XX в.

Образование Сибирского ханства стимулировало следующий шаг в развитии социально-экономических отношений между населением отдельных районов лесостепной полосы Западной Сибири. Это государственное образование объединило население на определенном уровне развития общества, родовых и феодальных отношений - тем самым вовлекло все населе- ние в единую организационную систему. Это нашло свое отражение и в археологических материалах. Постепенно распространяется мусульманский обряд погребений. В настоящее время подобных комплексов исследовано не много, но имеющиеся материалы позволяют говорить, что погребальные мусульманские комплексы первоначально формируются вокруг или близь «астана», а уже потом начинают возникать непосредственно около поселений. Стандартизируется керамика, практически на всех крупных поселениях и городах ханства мы выделяем комплекс круглодонной посуды со сплошной орнаментацией крупным подтреугольным штампом. Пока под вопросом находятся денежное обращение и система мер и весов, но находки монет и предметов, связанных с торговым оборотом, позволяют сделать это предположение. Определенная стандартизация наблюдается и в фортификационной системе городов, особенно пограничных городков, что позволяет нам выделять ее как определенный маркер государственности.

Суммируя все вышесказанное, мы можем говорить о том, что государственное объединение стало одним из слагающих факторов в формировании сибирских татар. После присоединения Сибири к Московскому царству новая администрация, стремясь предотвратить этот процесс консолидации, ввела свое административное деление в Западной Сибири, поделив ее на воеводства, уезды и тем самым поставив между группами дополнительные административные барьеры. Население вошло в другое государственное образование, т.е. один связующий государственный фактор был заменен на другой. Отличие было в том, что из его управляющих структур было исключено аборигенное население. Привлечение родовой верхушки к управлению в первый период присоединения имело место, но было эпизодическим и быстро кончилось. Татарской знати было необходимо компенсировать потерю власти, и она нашла выход, который заключался в том, что она возглавила процесс исламизации тюркоязычного населения. Из ее среды сформировалось мусульманское духовенство, которое продолжило политику укрепления основ религии среди местного населения. Сменив светскую власть на духовную знать, сохранила за собой контроль над обществом и свое положение и, самое главное, взяла на себя продолжение процесса консолидации тюркоязычного населения Западной Сибири.

Проводимые в последние годы археологические исследования погребальных и поселенческих памятников XVI-XVIII вв. в лесостепной полосе Западной Сибири позволяют констатировать их еще большее сближение по сравнению с предыдущим временем [5. С. 152]. Здесь следует отметить, что в данном сближении огромную и решающую роль сыграли переселенцы из европейской части российского государства. Расселяясь зачастую чересполосно с местным населением, они принесли с собой более высокий уровень развития экономики, материальной культуры. Это привело к тому, 
что аборигенное население практически по всем направлениям своего жизнеобеспечения за довольно короткий срок растеряло свои традиции и восприняло принесенные.

Констатируя русское влияние, нельзя не отметить, что сибирские татары в XVII-XX вв. уже в рамках нового государства и проживания чересполосно или совместно с переселенческим населением развивали свою систему хозяйства и систем жизнеобеспечения. При полной переориентации жилищных и хозяйственных комплексов на русские традиции татары привнесли в них свои культурные элементы, некоторые из которых сохраняются до настоящего времени. Это касается внутренней планиграфии жилищ и их убранства, декоративных элементов и т.д. В хозяйственных комплексах следует выделить особенности построек для зимнего содержания домашних животных и для хранения собранных и добытых припасов. Сибирские татары сохранили основные приемы ловли рыбы - по сей день фиксируется использование ими традиционных ставных ловушек, запорных устройств и котцов. Подобные черты мы можем выделить и в других отраслях хозяйства и промыслах сибирских татар.

Тюркоязычное население Западной Сибири под влиянием преимущественно политических событий (а не экономических) оказалось достаточно соорганизаванным к последней трети XVI в., т.е. готовым к дальнейшему сближению и превращению в единый этнос, но этот процесс стал развиваться уже в других условиях - после присоединения Западной Сибири к российскому государству - в XVII-XIX вв. Ключевую роль в этом сыграла татарская родовая знать и переселившееся из Средней Азии и Поволжья мусульманское население, а решающим фактором - исламизация всего тюркоязычного населения. К сожалению, следует констатировать, что на настоящее время этот важнейший момент в истории самого многочисленного в Сибири народа так и не описан. Необходим целый комплекс исторических, этнографических, археологических и генетических исследований, чтобы совершенно точно выяснить, когда окончательно сформировался этнос сибирские татары.

\section{ЛИТЕРАТУРА}

1. Томилов Н.А. Тюркоязычное население Западно-Сибирской равнины в конце XVI - первой четверти XIX вв. Томск : Изд-во Том. ун-та, 1981. $276 \mathrm{c}$

2. Исхаков Д.М., Измайлов И.Л. Этнополитическая история татар (III - середина XVI вв.) Казань : РИЦ «Школа», 2007. 356 с.

3. Голдина Р.Д. Городище Кучум-Гора // Вестник археологии Урала. 1969. Вып. 8. С. $138-159$.

4. Матвеев А.В., Татауров С.Ф. Средневековое городище Екатерининское V (итоги работ 2005 г.) // Тарское Прииртышье и проблемы сохранения историко-культурного наследия малого исторического города России. Тара, 2006. С. 65-66.

5. Матвеев А.В., Татауров С.Ф. Проблемы культурно-хронологической интерпретации памятников XIV-XVI вв. в Среднем Прииртышье // Время и культура в археолого-этнографических исследованиях древних и современных обществ Западной Сибири и сопредельных территорий: проблемы интерпретации и реконструкции : матер. Зап.-Сиб. археол.-этнограф. конф. Томск : Изд-во Том. ун-та, 2008. C. $149-152$

Tataurov Sergey F. Omsk branch of Institute of archeology and ethnography of the Siberian Branch of the Russian Academy of Science (Omsk, Russia). E-mail: TatSF2008@rambler.ru

PROCESSES OF CONSOLIDATION OF THE SIBERIAN TATARS BEFORE ACCESSION OF SIBERIA TO RUSSIA.

Keywords: Siberia; population; economy; religion; consolidation.

Process of consolidation of the Turkic population of Western Siberia has taken the considerable period of time, actually all the II millennium AD. The territory of a forest-steppe zone of Western Siberia with the population living on her to the middle of the 16th century represented, telling expressed by archaeological terminology, a historical and cultural community. In general for all region it was expressed in a certain proximity of material and spiritual culture with the local options gravitating towards valleys of the large rivers -Tobol, Ishim, Irtysh and Ob. Duration of process of rapprochement of the Turkic population has been caused by several factors. First of all, the significant role in it was played that their resettlement to Western Siberia has dragged on more than one thousand years. Also places of an exit of groups of the Turkic population which varied from the foothills of Altai to Central Asia and the Volga region had considerable value. Actually process of formation of uniform ethnos of the Siberian Tatars has begun with inclusion of a forest-steppe strip of Western Siberia in the Mongolian empire. Archaeological materials of the first half of II millennium $\mathrm{AD}$ at all variety of the population of a forest-steppe strip of Western Siberia give us quite steady Turkic background on all key elements of material and spiritual culture. By the time of Western Siberia joining the Moscow kingdom there is a certain unification of economy, which becomes complex - consisting of the appropriating branches - hunting, fishery and collecting and making - cattle breeding and agriculture. Formation of the Siberian khanate stimulated the following step in development of the social and economic relations between the populations of certain regions of a forest-steppe strip of Western Siberia. This state education has united the population at a certain level of development of society, the patrimonial and feudal relations - thereby it has involved all population in uniform organizational system. It has found the reflection in archaeological sites of this time - settlement and funeral complexes, life support systems etc. The Turkic population of Western Siberia under the influence of mainly political events was rather in arranging to the last third of the 16th century, but this process began to develop already in other conditions - after accession of Western Siberia to the Russian state - in the XVII-XIX centuries. The key role in it was played by the Tatar nobility and the moved Muslim population from Central Asia and the Volga region, and a decisive factor - Islamization of all Turkic population.

\section{REFERENCES}

1. Tomilov, N.A. (1981) Tyurkoyazychnoe naselenie Zapadno-Sibirskoy ravniny v kontse XVI-pervoy chetverti XIX vv. [The Turkic-speaking population of the West Siberian Plain in the late 16th - early 19th centuries]. Tomsk: Tomsk State University. 
2. Iskhakov, D.M. \& Izmaylov, I.L. (2007) Etnopoliticheskaya istoriya tatar (III - seredina XVI vv.) [Ethno-political history of the Tartars (the 3rd mid-16th centuries)]. Kazan: Shkola.

3. Goldina, R.D. (1969) Gorodishche Kuchum-Gora [The Mound Kuchum-Gora]. Vestnik arkheologii Urala. 8. pp. 138-159.

4. Matveev, A.V. \& Tataurov, S.F. (2006) Srednevekovoe gorodishche Ekaterininskoe V (itogi rabot 2005 g.) [The medieval settlement Ekaterininskoe V (the results of the work in 2005)]. In: Kazeko, T.N. (ed.) Tarskoe Priirtysh'e i problemy sokhraneniya istoriko-kul'turnogo naslediya malogo istoricheskogo goroda Rossii [The Irtysh near Tara and problems of preservation of historical and cultural heritage of the Russian small historical towns]. Tara: Omsk State Agrarian University. pp. 65-66.

5. Matveev, A.V. \& Tataurov, S.F. (2008) [Cultural and chronological interpretation of the 14th-16th monuments in the Middle Irtysh]. Vremya i kul'tura $v$ arkheologo-etnograficheskikh issledovaniyakh drevnikh i sovremennykh obshchestv Zapadnoy Sibiri i sopredel'nykh territoriy: problemy interpretatsii $i$ rekonstruktsii [Time and culture in archaeological and ethnographic studies of ancient and modern societies of West Siberia and crossborder regions: Problems of interpretation and reconstruction]. Proc. of the West Siberian Archeological and Ethnographic Conference. Tomsk: Tomsk State University. pp. 149-52. (In Russian). 